\title{
屋上設置壁のある大規模建築物の屋根面に作用する風圧力の性状 CHARACTERISTICS OF WIND PRESSURE ON ROOFS OF LARGE-SCALE BUILDINGS WITH WALLS ON THE ROOFTOP
}

\author{
服部 彰仁*1, 徳井公彰*1, 箕輪 健 - *2, \\ 小河利行*3, 増田圭司 ${ }^{* 4}$, 佐々木 康人*5 \\ Akihito HATTORI, Masaaki TOKUI, Ken'ichi MINOWA, \\ Toshiyuki OGAWA, Keiji MASUDA and Yasuhito SASAKI
}

\begin{abstract}
In the case of large-scale buildings, walls or tall parapets are often attached on the outer periphery of the roofs in order to screen the drainage gradient or accommodate machinery on the rooftop. Previous studies have been conducted on the effect of parapets on the wind pressure and the efficacy of porous parapets in mitigating peak wind pressure. But there are a variety of factors, such as height of parapets, overall scale and shape of buildings and the characteristics of approach flows, whose influences have not previously been well elucidated. In this paper, wind tunnel tests and fluid analyses using rigid models are conducted, and the influence of each factor on wind pressure was analyzed.
\end{abstract}

Keywords : Large-scale roof, Wind tunnel test, Fhid analysis, Wall on rooftop, Wind pressure coefficient 大規模屋根，風洞実験，流体解析，屋上設置壁，風圧係数

1. 序

近年，国内外において半導体や液晶パネル事業を行う大規模工場 や物流倉庫の建設が盛んになっている。これら大規模建築物の多く には，意匠，計画的な観点から，屋根の水勾配や屋上の機械設備を 隠すこと, 広告の設置を目的として, 屋上外周部に壁が設けられる。 この屋上設置壁が屋根面に作用する風圧力に及ぼす影響に関しては,

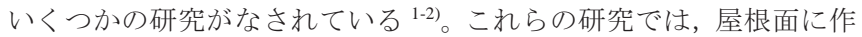
用寸る風圧力は屋上設置壁が高くなるに伴い低減されるとしており， Euro Code ${ }^{3)}$ においても屋上設置壁によって屋根面に作用寸る風圧力 は最大で 3 割程度低減できるとされている。しかし, 建物形状や気 流性状, 屋上設置壁高さなどの様々な要因が関わるため, 屋上設置 壁による屋根面に作用寸る風圧力の低減効果は未だ明確になってい ない。このため, 設計に用いられる建築基準法 ${ }^{4)}$ や日本建築学会建 築物荷重指針 5)（以下，荷重指針）などの日本の規基準では，屋上 設置壁が屋根面に作用する風圧力に与える影響に関する評価方法は 定められていない。

既往の研究 6)では, 矩形平面を有する建築物に対して斜めから風 が当たるとき, 風上側隅角部を起点として円錐形の一対の渦が左右 交互に屋根上部に形成されることを確認している。この渦により生 じる局所的な強い風圧力は，屋根莫き材等の外装材に損傷を与える 原因となる。しかし, それらの円錐渦の性状に関寸る既往研究では,
屋上設置壁が設けられている場合は想定されていない。また，屋根

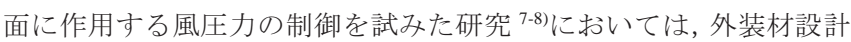
用のピーク風圧力の低減に対して屋上設置壁に開口（孔）を設ける ことが効果的であるとされている。つまり，屋上設置壁に開口を設 けることで, 屋根の水勾配や屋上の機械設備を隠すという意匠・計 画的な要件を満足しながらも外装材の設計荷重を低減することがで きる可能性が示唆されている。

そこで本研究では, 屋上設置壁のある大規模建築物を対象に, 屋 根面に作用寸る風圧力の性状を明らかにすることを目的とする。ま ず，風洞実験により風向角や軒高さ，屋上設置壁の高さが屋根面に 作用寸る風圧力に与える影響について分析を行う。また，数值流体 解析により構造物周辺の流れ場の状況を推測するとともに，風洞実 験結果に対する固有直交関数展開 ${ }^{9}$ により風圧力場の組織的な構造 を明らかにし，風圧力の性状と渦の関係について考察を加える。さ らに屋上設置壁の高さ，構造物の平面形状，屋根勾配，気流性状と 各圧力測定点における全測定風向中の最小のピーク風圧力の分布性 状の関係について分析を行う。加えて, 風洞実験において開口を有 する屋上設置壁を陸屋根に付加し屋根面の風圧力を測定することで, その開口の量と外装材設計用のピーク風圧力の関係について分析を 行う。
*1 元 東京工業大学大学院理工学研究科建築学専攻 大学院生

*2 日本工業大学工学部建築学科 助教・博士 (工学)

*3 東京工業大学 名誉教授. 工博

*4 (侏)ジタ技術センター 博士 (工学)

*5 (株フジタ技術センター 工修
Former Grad. Stud., Dept. of Arch. and Build. Eng., Tokyo Institute of Technology Assist. Prof., Dept. of Architecture, Nippon Institute of Technology, Dr.Eng. Prof. Emeritus, Tokyo Institute of Technology, Dr.Eng.

Technology Development Division, FUJITA Corporation, Dr.Eng.

Technology Development Division, FUJITA Corporation, M.Eng. 


\section{2. 風洞実験及び数値解析の概要}

本研究では, 図 1 に示寸矩形平面を持つ屋上設置壁のある建築物 を対象とする。表 1 に示寸通り, 平面形状は一辺 $D^{\text {full }}$ が $100 \mathrm{~m}$ の正 方形平面と短辺 $D^{\text {full }}$ が $100 \mathrm{~m}$, 長辺 $B^{\text {full }}$ が $200 \mathrm{~m}$ の長方形平面を想 定し, 軒高さ $H^{\text {full }}$ を $10,20,40 \mathrm{~m}$, 屋上設置壁高さ $h_{p}$ full を $0.0,1.0,2.5$, 5.0, 7.5, $10.0 \mathrm{~m}$ とした。実験及び解析におけるモデル, 気流の縮尺 率は $1 / 222$ とし, 短辺 $D^{\text {model }}$ は $450 \mathrm{~mm}$, 軒高さ $H^{\text {model }}$ は 45, 90, $180 \mathrm{~mm}$ である。実験及び解析の基準風速 $U_{H}$ model は軒高さ $H^{\text {model }}$ の最大 (180mm)で約 $8 \mathrm{~m} / \mathrm{s}$ とした。モデルごとに軒高さが異なるため, 得ら れた結果は, アスペクト比の影響ではなく, 軒高さそのものの影響 が含まれたものとして評価される。なお各変数の添字は, 実建物ス ケールのときに full を, 実験及び解析モデルスケールのときに model を用いて区別している。

\section{1. 風洞実験概要}

風洞実験は（株）フジタ技術センター所有のゲッチンゲン型境界 層風洞を用いて行った。測定風洞断面は幅 $3.0 \mathrm{~m}$, 高さ $1.8 \mathrm{~m}$ であり, 吹走部長さは約 $20 \mathrm{~m}$ である。

風圧模型（剛模型）は，写真 1 に示す水平な屋根面を持つ正方形 陸屋根模型（図 1 (a)），長方形陸屋根模型（図１(b)），5\%の勾 配を有する屋根面を持つ正方形片流れ屋根模型（図 1 (c) ) の 3 種 を用いた。屋根面及び壁面は ABS 樹脂を用い, 屋上設置壁は厚さ $1.5 \mathrm{~mm}$ のアルミ板を用いて作製した。

風圧力測定孔は，図 1 の斜線部に示すように建物の対称性を考慮 して風圧模型の屋根面の $1 / 2$ の範囲に配置し, 図 2 に示すように隅 角部で細かくなるように計 224 点設けた。風圧力は，測定孔に取り 付けた長さ $800 \mathrm{~mm}$ のビニルチューブを介して, 多点同時圧力測定 システムにより測定を行った。計測された圧力は，チュービングに 伴う振幅, 位相の特性について周波数補正を行った ${ }^{10)}$ 。サンプリン グ周波数は $500 \mathrm{~Hz}$, データ数 65536 , 計測時間は約 132 秒とした。 風速は, 風洞内模型中央上部の高さでピト一管により測定した速度 圧から算出した。なお本研究では対称性を考慮し, 大きなピーク風 圧力が作用すると考えられる屋根面の風上側 $1 / 4$ を風圧力の評価範 囲（図 1 に示寸網掛け部）とした。風圧力は, 軒高さにおける風速 $U_{H}{ }^{\text {model }}$ より算出した速度圧を用いて計測值を無次元化して風圧係数 として表す。また, 最小ピーク風圧係数は, $1 \mathrm{~m}^{2}$ の受圧面積を想定 L TVL 法 ${ }^{111}$ に基づいて各風向, 各測定孔における風圧力の時刻歴 データに実スケール 0.12 秒相当の移動平均処理を施し実時間 10 分 間における風圧係数の最小值 8 サンプルのアンサンブル平均とした。 なお, 最小ピーク風圧係数の全風向中における最小值を全風向最小 ピーク風圧係数とした。風向 $\theta$ は図 1 に示寸ように時計回りに $0^{\circ}$ か ら $90^{\circ}$ までを $5^{\circ}$ 間隔で, 全 19 風向とした。図 3 に示寸実験気流は荷 重指針に記される地表面粗度区分 II（Flow1），IV（Flow2）に相当 する乱流境界層流を, 模型の風上側に配置したスパイヤとラフネス により作成した。

\section{2. 数值解析概要}

数值解析は三次元非圧縮性粘性流体解析である。流れ場の支配方 程式は非圧縮性粘性の N avier-Stokes 方程式と連続式である。計算ア ルゴリズムは IBTD +FS 法に基づく。時間積分には Crank-Nicolson 法を, 空間方向の離散化には有限要素法を用い, 要素には四面体一

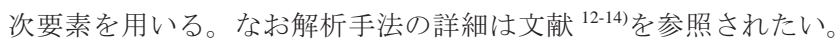

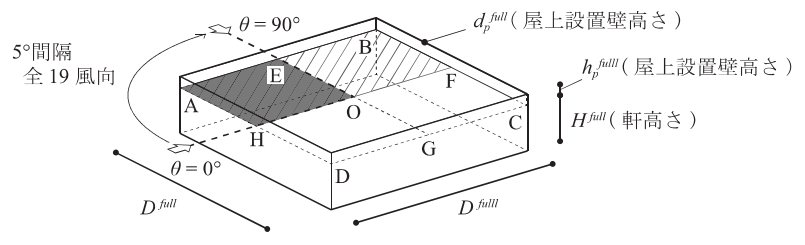

(a) 正方形陸屋根

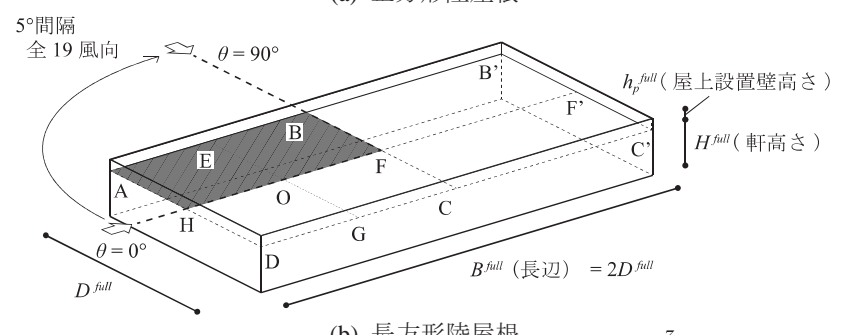

(b) 長方形陸屋根
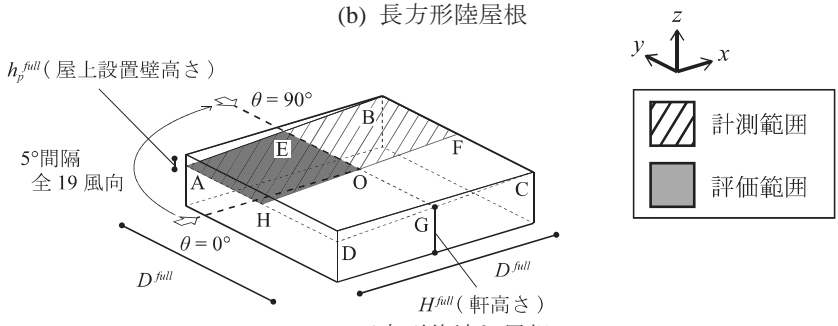

(c) 正方形片流れ屋根

図 1 対象構造物

表 1 実験パラメータ

\begin{tabular}{c|c}
\hline 模型と気流の縮尺率 & $1 / 222$ \\
\hline 平面形状 $\left(B^{\text {full }} \times D^{\text {full }}\right)$ & 正方形 $(100 \mathrm{~m} \times 100 \mathrm{~m})$, 長方形 $(200 \mathrm{~m} \times 100 \mathrm{~m})$ \\
\hline 屋根勾配 & 陸屋根 $(0 \%)$, 片流れ $(5 \%)$ \\
\hline 軒高さ $H^{\text {full }}(\mathrm{m})$ & $10,20,40$ \\
\hline 屋上設置壁高さ $h_{p}^{\text {frul }}(\mathrm{m})$ & $0.0,1.0,2.5,5.0,7.5,10.0$ \\
\hline 屋上設置壁厚さ $d_{p}^{\text {frul }}(\mathrm{m})$ & 0.33 \\
\hline 地表面粗度区分 & II, IV \\
\hline 風向 $\theta$ & $0^{\circ} \sim 90^{\circ}\left(5^{\circ}\right.$ 間隔 $)$ \\
\hline
\end{tabular}

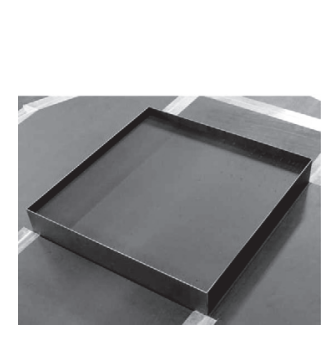

写真 1 正方形陸屋根模型

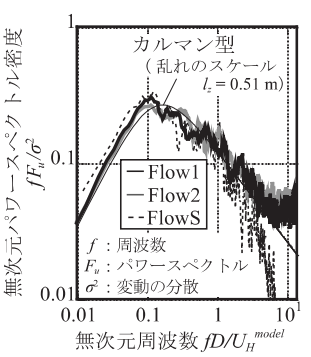

(a) 変動風速 0 パワースペクトル密度

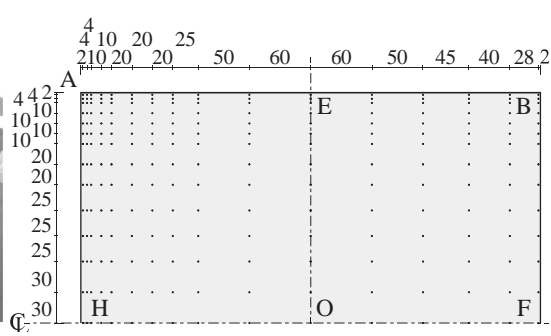

図 2 風圧力測定孔の配置（単位： $\mathrm{mm}$ )

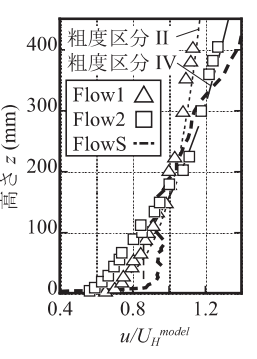

(b) 平均風速 $u / U_{H}{ }^{\text {model }}$

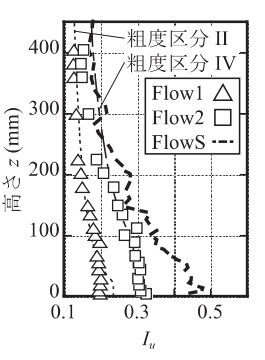

(c) 気流の乱れ強さ
図 3 気流性状

表 2 解析諸元

\begin{tabular}{c|c|c|c|c|c|c}
\hline $\begin{array}{c}\text { 基淮風速 } \\
U_{H}^{\text {model }}\end{array}$ & $\begin{array}{c}\text { 空気密度 } \\
\rho\end{array}$ & $\begin{array}{c}\text { 粘性係数 } \\
\mu\end{array}$ & $\begin{array}{c}\text { Reynolds 数 } \\
R_{e}\end{array}$ & $\begin{array}{c}\text { 基準長さ } \\
D^{\text {model }}\end{array}$ & $\begin{array}{c}\text { 基準高さ } \\
H^{\text {model }}\end{array}$ & $\begin{array}{c}\text { 無次元時間刻み } \\
\Delta t^{*}\end{array}$ \\
\hdashline$(\mathrm{m} / \mathrm{s})$ & $\left(\mathrm{kg} / \mathrm{m}^{3}\right)$ & $\left(\mathrm{N} \cdot \mathrm{s} / \mathrm{m}^{2}\right)$ & $\left(=\rho U_{H}^{\text {model }} D^{\text {model }} / \mu\right)$ & $(\mathrm{m})$ & $(\mathrm{m})$ & $\left(=t U_{H}^{\text {model }} / D^{\text {mode }}\right)$ \\
\hline \hline 8 & 1.25 & $1.81 \times 10^{3}$ & $2.5 \times 10^{5}$ & 0.45 & 0.2 & 0.001 \\
\hline \hline
\end{tabular}


本解析は実験モデルスケールで行い, 構造物一辺の長さ $D^{\text {model }}=$ $450 \mathrm{~mm}$ を基準長さとし, 解析領域は主流方向に $17.8 D^{\text {model }}$, 主流方 向に直交する水平方向に $10 D^{\text {model }}$, 鈆直方向に $11 D^{\text {model }}$ とする。構造 物表面は, 幅・奥行き方向ともに 88 分割, 高さ方向に 25 分割し節 点を配置する。また, 屋上設置壁は高さ方向に 10 分割, 厚さ方向に 1 分割とする。床面及び物体表面では Non-Slip 条件, 解析領域の側 面及び上側はF ree-Slip 条件, 流出面については, 圧力を 0 とする境 界条件と寸る。流入境界条件には, 前もって別の解析領域で生成し た流入変動風を用いる ${ }^{14-15)}$ 。図 3 に示寸解析で用いる気流 (FlowS) の平均風速と乱れ強さは, 高さ $100 \mathrm{~mm}$ 以上においては概㸚実験気 流 Flow2 と一致しているが, 高さ $100 \mathrm{~mm}$ 以下においては平均風速 がやや強く，乱れ強さも大きめである。基準高さ $H^{\text {model }}(=180 \mathrm{~mm})$ での変動風速のパワースペクトル密度については, メッシュの大き さに依存して高周波成分が小さいものの，高周波成分以外において は概ね対応している。本解析における諸元は表 2 に示寸通りである。

\section{3. 屋上設置壁が正方形平面を持つ陸屋根の風圧カに与える影響}

\section{1. 風洞実験から得られた最小ピーク風圧カの性状}

屋上設置壁高さが 0.0，5.0 m における正方形陸屋根模型（軒高さ $20 \mathrm{~m}$ ）の最小ピーク風圧係数分布を図 4 に示寸。屋上設置壁高さに よらず，風向が $0^{\circ}$ から $45^{\circ}$ へ変化するに伴い，縁に平行するように 走っていた等圧線が傾いた。いずれの風向でも, 屋上設置壁の付加 によって風上側において最小ピーク風圧係数の絶対值は低減された。 一方で, 最小ピーク風圧係数が -2 を下回る領域は屋根の中央へ向 けて広がった。つまり, 正方形陸屋根に屋上設置壁を付加すること で, 屋根面に作用寸る最小ピーク風圧力の絶対值は, 風上側隅角部 や縁部で減少し中央部で増加した。

屋上設置壁高さが $0.0 \mathrm{~m}$ の場合, 風向 $45^{\circ}$ から多少ずれた $40^{\circ}$ にお いて最小ピーク風圧係数の屋根面上の最小值が -8.8 と全風向の中 で最小值をとった。このような非常に大きな負圧は, 3.5 節で後述 するように, 屋根端部の極近傍に測定孔が配置されているため計測 されたと考えられる。

\section{2. 構造物周りの流れ場の変化}

図 5 に数值解析による風向 $0^{\circ}, 45^{\circ}$ の構造物周りにおける流線を示 す。風向 $0^{\circ}$ の $y=0$ の断面において, 縁に生じる強い負圧の原因と なる剥離流が，屋上設置壁を付加することで屋根面から離れること が確認できる。一方, $x=0$ の断面では, 屋上設置壁の付加によって 屋上設置壁の内側に小さな渦が確認できるが，大きな負圧の原因と なるような流れ場の特徴は見られない。

風向 $45^{\circ}$ の断面においては，屋上設置壁の有無に関わらず屋根上 部に一対の渦が確認できる。この円錐渦が風上側隅角部に作用寸る 強い負圧と変動の原因であると考えられる。風向 $0^{\circ}$ における剥離流 と同様に, 屋上設置壁の付加により円錐渦が屋根面から離れること が確認でき，屋根面への影響が小さくなると考えられる。

なお，これらの結果は 2.2 節に述べたように接近流の性状が実験 とはやや異なり, 模型高さ $100 \mathrm{~mm}$ 以下において平均風速, 乱れ強 さがともに強い場合のものである。

\section{3. 屋根面の風圧力場}

実験により得られた変動風圧力に対し, 固有直交関数展開 (POD 解析）9を行い，ランダムな変動内の組織的構造の解明を試みた。
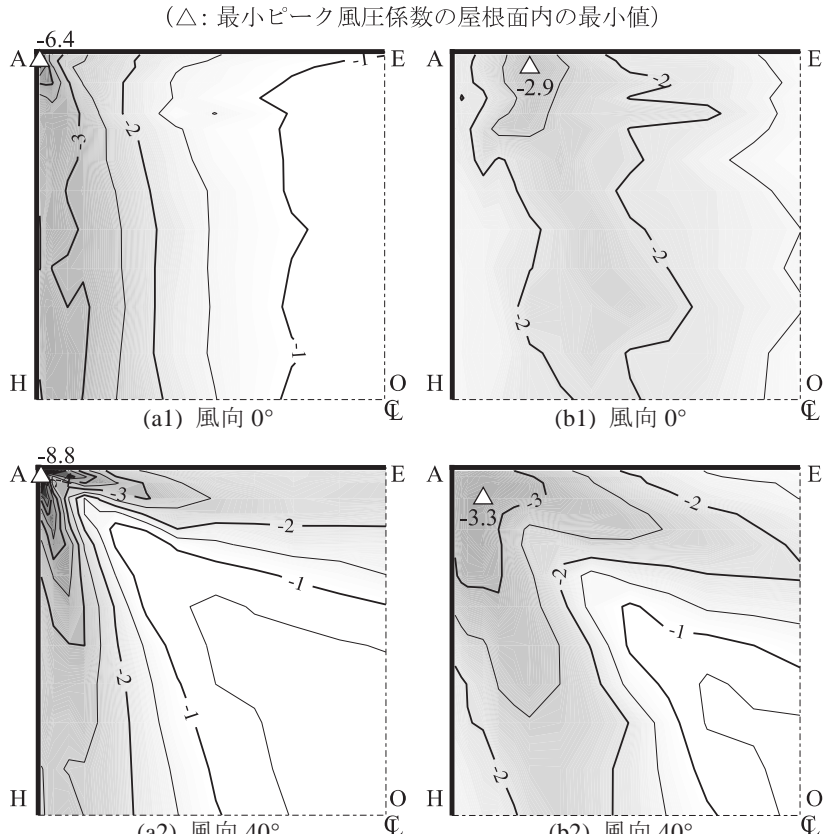

(a2) 風向 $40^{\circ}$

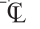

(b2) 風向 $40^{\circ}$

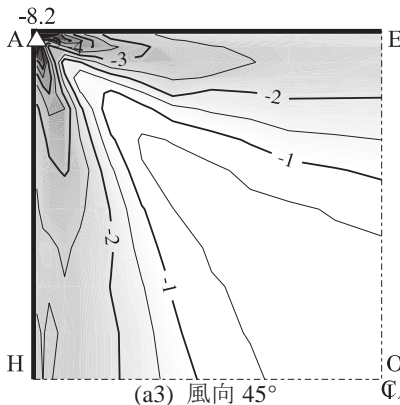

(a) 屋上設置壁高さ $0.0 \mathrm{~m}$

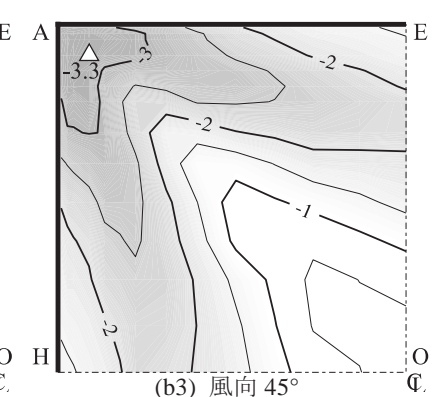

(b) 屋上設置壁高さ $5.0 \mathrm{~m}$

図 4 正方形陸屋根における最小ピーク風圧係数に 屋上設置壁が与える影響（軒高さ $20 \mathrm{~m}$ )
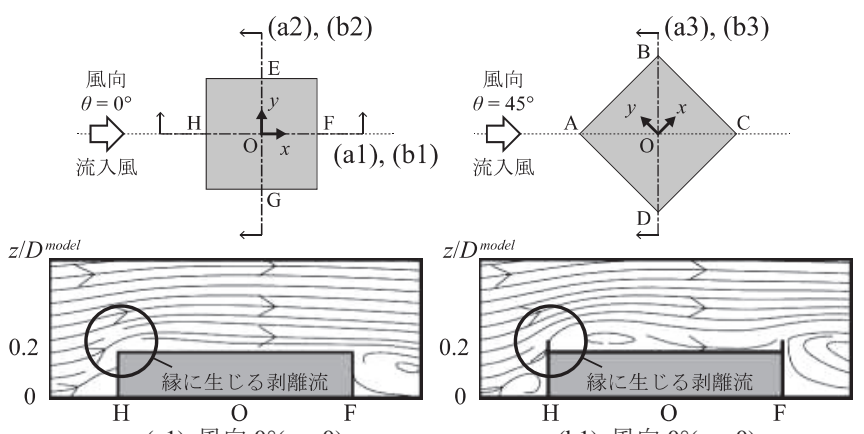

(a1) 風向 $0^{\circ}(y=0)$
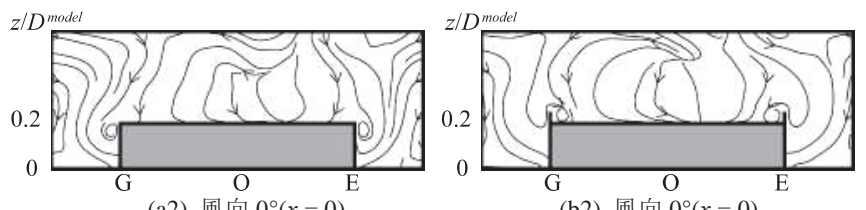

(b2) 風向 $0^{\circ}(x=0$

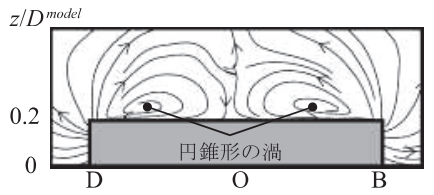

(a3) 風向 $45^{\circ}(x=y)$

(a) 屋上設置壁高さ $0.0 \mathrm{~m}$

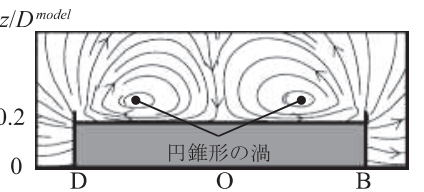

(b3) 風向 $45^{\circ}(x=y)$ (b) 屋上設置壁高さ $5.0 \mathrm{~m}$

図 5 屋上設置壁の付加による流線の変化 
得られた固有風圧モードの寄与率を図 6 に示す。 5 次までの固有風 圧モードの寄与率, 及び 20 次までの累積寄与率は, 軒高さと屋上設 置壁高さに対し大きく変化しなかったが，軒高さの増加に伴い低次 モードの寄与率が若干大きくなる傾向が見られた。

寄与率が最大である 1 次固有風圧モードを図 7 に示す。屋上設置 壁高さが $0.0 \mathrm{~m}$ における 1 次固有風圧モードにおいて, 隅角部から のびる左右逆対称形の分布性状が，軒高さの増加に伴い顕著に見ら れるようになった。これは, 隅角部から一対の円錐渦が交互に発生 するスイッチングによるものであると考えられる ${ }^{6)}$ 。また，屋上設 置壁高さが $5.0 \mathrm{~m}$ における 1 次固有風圧モードは, 軒高さによらず 非常に近い分布性状をとった。図示していないが屋上設置壁高さが $5.0 \mathrm{~m}$ を超えた場合, 屋根面上の風圧力場は概初同様となった。

\section{4. 全風向最小ピーク風圧カとその発生風向}

図 8 に, 実験により得られた軒高さが $10 \mathrm{~m}, 40 \mathrm{~m}$ の正方形平面を 持つ陸屋根の全風向最小ピーク風圧係数分布を示す。また，この最 小值が生じた風向を図 8 中に矢印を用いて併せて示す。

軒高さ $H^{\text {full }}=10 \mathrm{~m}$

屋上設置壁高さが $0.0 \mathrm{~m}$ では縁に平行に走った等值線が, 屋上設 置壁の付加によって, 風上側隅角部から縁に対して傾き, 隅角部や 縁の負圧は低減された。屋上設置壁高さが $2.5 \mathrm{~m}$ のとき, 円錐渦が 原因であると考えられる負圧の大きな領域は隅角部から屋根中央へ 広がった。一方, 屋上設置壁高さが $5.0 \sim 10.0$ m では, 隅角部から 広がる負圧の大きな領域も含め, 屋根面の全域において負圧が低減 された。全風向最小ピーク風圧係数の最小值を生じる位置は屋上設 置壁高さが高くなるに伴い, 風上側の隅角部から風下側へと移動し た。全風向最小ピーク風圧係数を生じる風向は, 屋上設置壁が無い ときはその多くが壁面に垂直な風向 $0^{\circ}, 90^{\circ}$ であるのに対し, 屋上設 置壁が高くなるにつれて壁面に対して斜め方向である風向 $45^{\circ}$ 付近 となった。

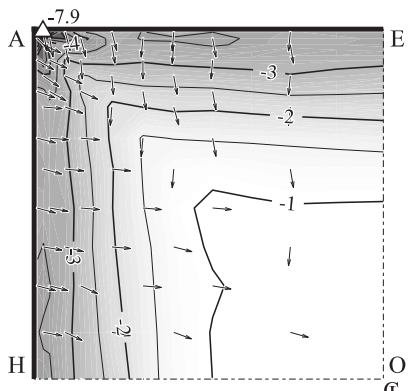

(a1) 屋上設置壁高さ $0.0 \mathrm{~m}$

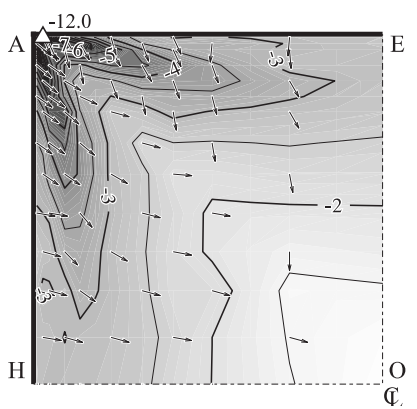

(b1) 屋上設置壁高さ $0.0 \mathrm{~m}$

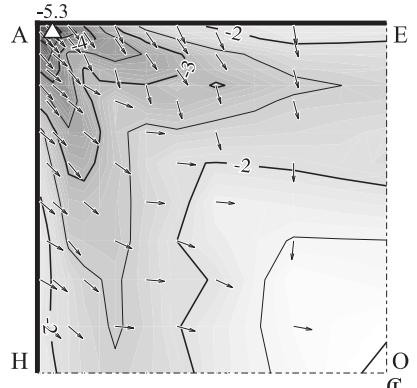

(a2) 屋上設置壁高さ $2.5 \mathrm{~m}$

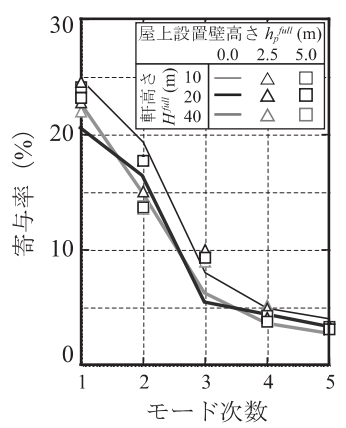

(a) 寄与率

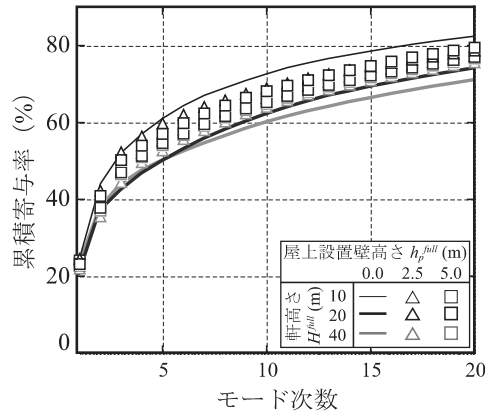

(b) 累積寄与率
図 6 固有風圧モードの寄与率に対して屋上設置壁が与える影響 (正方形陸屋根, 風向 $45^{\circ}$ )

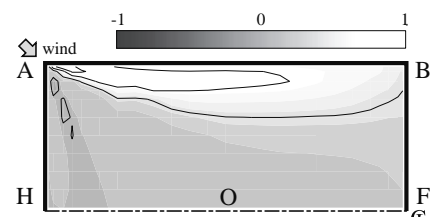

(a1) 軒高さ $10 \mathrm{~m}$

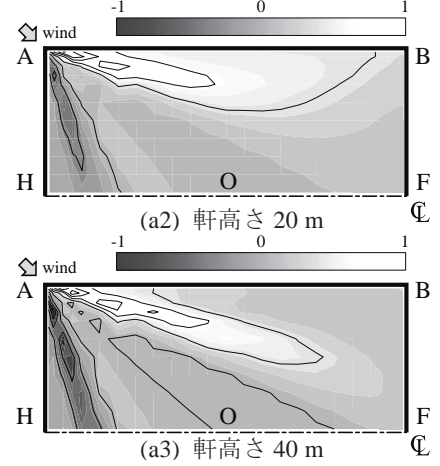

(a) 屋上設置壁高さ $0.0 \mathrm{~m}$

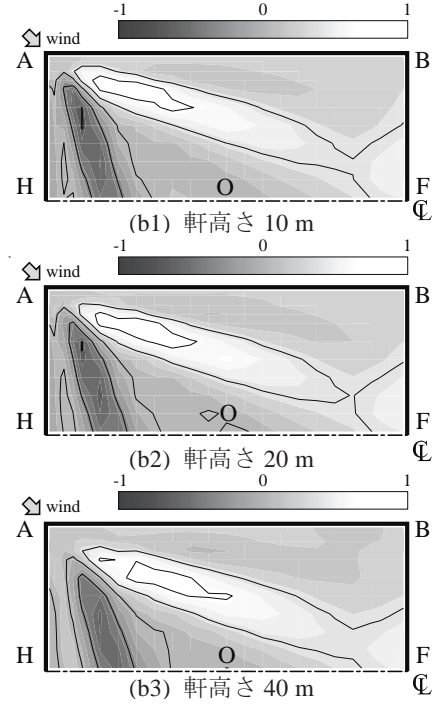

(b) 屋上設置壁高さ $5.0 \mathrm{~m}$
図 71 次固有風圧モードに屋上設置壁が与える影響 (正方形陸屋根, 風向 $45^{\circ}$ )

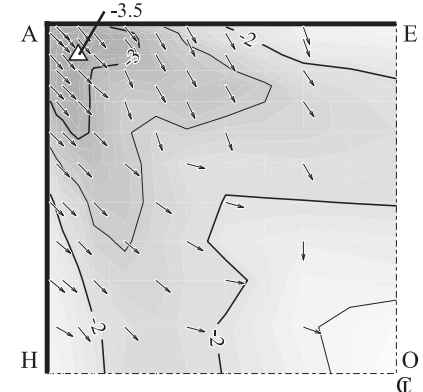

(a3) 屋上設置壁高さ $5.0 \mathrm{~m}$

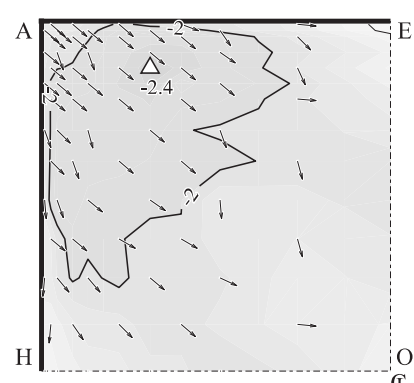

(a4) 屋上設置壁高さ $10.0 \mathrm{~m}$ ⿷ (a) 軒高さ $10 \mathrm{~m}$

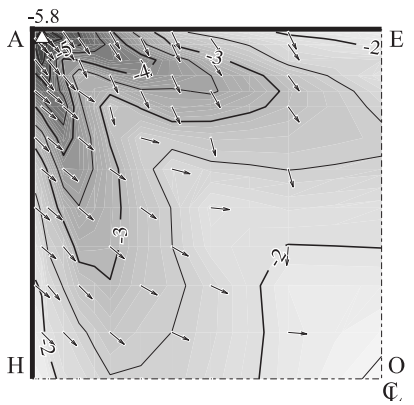

(b2) 屋上設置壁高さ $2.5 \mathrm{~m}$

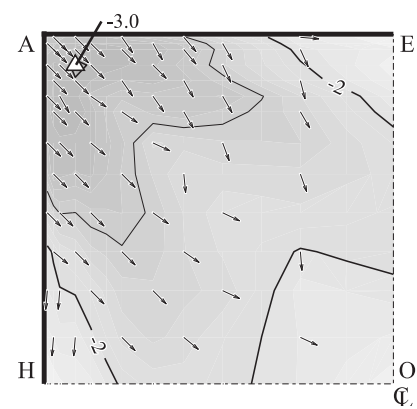

(b3) 屋上設置壁高さ $5.0 \mathrm{~m}$

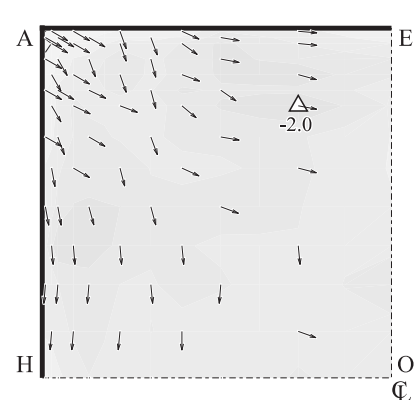

(b4) 屋上設置壁高さ $10.0 \mathrm{~m}$ 
軒高さ $H^{\text {full }}=40 \mathrm{~m}$

軒高さ $10 \mathrm{~m}$ と異なり, 屋上設置壁が無い場合においても壁面に対 して斜め方向である風向 $45^{\circ}$ 付近において多くの全風向最小ピーク 風圧係数が計測され, 円錐渦が原因であると考えられる負圧の大き な領域は隅角部から広がった。また, 屋上設置壁高さが $0.0 \sim 2.5 \mathrm{~m}$ において, 屋上設置壁によって全風向最小ピーク風圧係数の分布性 状は大きく変化しなかったが, 隅角部付近の全風向最小ピーク風圧 係数の絶対值は大きく低減された。屋上設置壁高さが $5.0 \sim 10.0 \mathrm{~m}$ では，軒高さが $10 \mathrm{~m}$ であるときと同様に屋根面の負圧は低減され た。屋上設置壁高さが $5.0 \mathrm{~m}$ 以上のとき, 屋根面上の全風向最小ピ 一ク風圧係数は軒高さに依らず概袮等しい分布性状をとった。ここ から, 屋根面に作用寸る風圧力に対する屋上設置壁の影響は, その 高さが $5.0 \mathrm{~m}$ 以上となるとき非常に大きくなり, それに比べて軒高 さの影響が非常に小さくなると考えられる。なお, 軒高さが $20 \mathrm{~m}$ のとき, 図示していないが軒高さ $10 \mathrm{~m}$ と $40 \mathrm{~m}$ の間の性状を示した。

\section{5. 全風向最小ピーク風圧カの最小値}

正方形平面の陸屋根の風上側前縁部である線分 $\mathrm{AE}$ 上 (屋根端部よ り $2 \mathrm{~mm}$ 内側の測定点）における全風向最小ピーク風圧係数分布を図 9に示す。全風向最小ピーク風圧係数の絶対值は, 屋上設置壁高さが $2.5 \mathrm{~m}$ 以下のとき隅角部である $\mathrm{A}$ 点の近傍において大きくなり, 屋上 設置壁高さが 1.0 mを下回る場合には絶対值が7を超えるような特に 大きなピーク風圧力が作用した。一方で屋上設置壁高さが $5.0 \mathrm{~m}$ を超 える場合には, 全風向最小ピーク係数の絶対值は $\mathrm{A}$ 点近傍において 低減され，線分 $A E$ 上でおおよそ一定值をとった。

正方形平面の陸屋根に作用する全風向最小ピーク風圧係数の最小 值と屋上設置壁高さの関係について, 実験結果を既往研究1), 16) と併 せて図10に示す。本実験と既往実験における全風向最小ピーク風圧 係数の最小值を比較すると, $h_{p}{ }^{\text {full }} / D^{\text {full }}=0.01$ 以下では本実験におい て-8 -12という值が計測され, 既往実験で計測された-6程度を大き く下回った。これは, 屋上設置壁が低い場合は図9に示すように隅角 部の極近傍において全風向最小ピーク風圧係数が計測されるため, 屋根端部から測定孔が5 mm以上離れている既往実験に比べて端部 から $2 \mathrm{~mm}$ の距離に測定孔を配置した本実験の方が, より大きな絶対 值を持つピーク風圧力を計測することができたからであると考えら れる。一方で, $h_{p}{ }^{\text {full }} / D^{\text {full }}=0.025$ 以上となるとき本実験と既往実験は よく対応する。以上は, 長方形平面についても同様の傾向を示した。

\section{4. 平面形状, 屋根勾配, 気流性状が風圧カに与える影響}

\section{1. 平面形状の影響}

軒高さが $10 \mathrm{~m}$ の長方形平面を持つ陸屋根に, 高さが $2.5 \mathrm{~m}$ 屋上設 置壁が付く際の全風向最小ピーク風圧係数の分布を図11に示寸。同 図のA 点を含む左側半分（破線で囲った範囲）と図8(a2)に示寸軒高 さが $10 \mathrm{~m}$, 屋上設置壁高さが $2.5 \mathrm{~m}$ の正方形平面を持つ陸屋根の全風 向最小ピーク風圧係数分布を比較すると, 概数等しい分布性状を示 した。長方形平面における図11のA 点を含む左側半分（破線で囲っ た範囲）の各測定点における全風向最小ピーク風圧係数を縦軸に, 正方形平面を持つ陸屋根の全風向最小ピーク風圧係数（図8(a2)）を 横軸にとり，比較した散布図を図12に示す。両モデルの各測定点に おける全風向最小ピーク風圧係数はよく対応し, 図10に破線で囲っ た風上側の範囲では平面形状の影響は見られなかった。

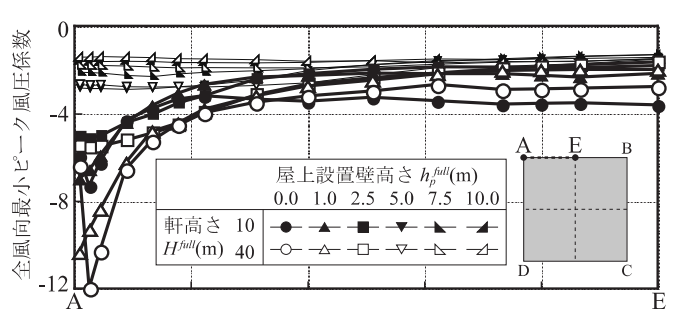

図 9 正方形陸屋根の線分 $A E$ 上における全風向最小ピーク風圧係数分布

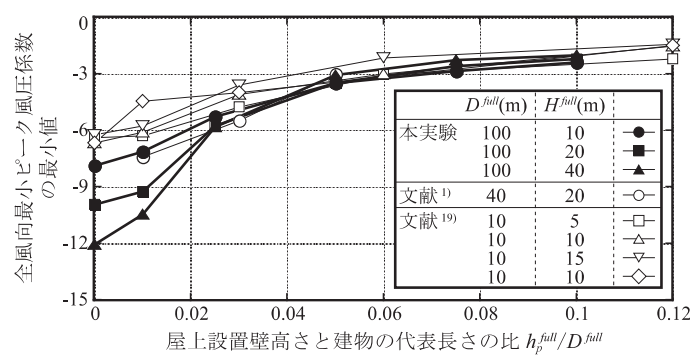

図 10 全風向最小ピーク風圧係数の最小値と屋上設置壁高さ $h_{p}{ }^{\text {full }}$ の関係

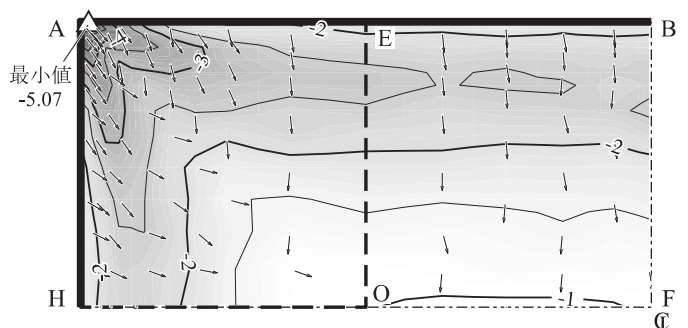

図 11 長方形陸屋根模型における全風向最小ピーク風圧係数の分布 （軒高さ $10 \mathrm{~m}$, 屋上設置壁高さ $2.5 \mathrm{~m}$ )

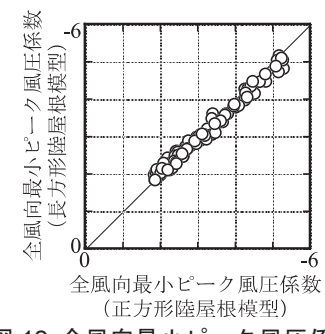

図 12 全風向最小ピーク風圧係数 に対する平面形状の影響

(軒高さ $10 \mathrm{~m}$, 屋上設置壁高さ $2.5 \mathrm{~m}$ )

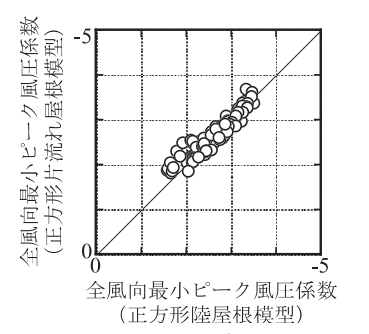

図 13 全風向最小ピーク風圧係数 に対する屋根勾配の影響

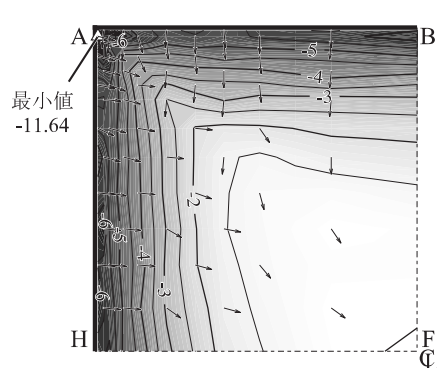

図 14 正方形陸屋根模型における全風向最小ピーク風圧係数の分布 (Flow2, 軒高さ $10 \mathrm{~m}$, 屋上設置壁高さ $0.0 \mathrm{~m}$ )

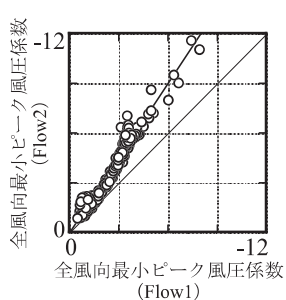

(a) 軒高さ $10 \mathrm{~m}$

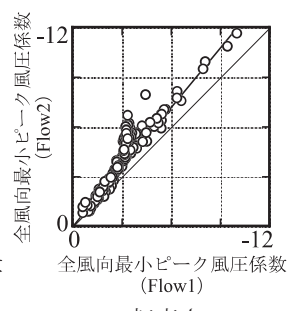

(b) 軒高さ $20 \mathrm{~m}$

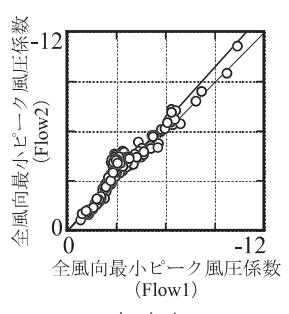

(c) 軒高さ $40 \mathrm{~m}$
図 15 気流の乱れ強さが全風向最小ピーク風圧係数に与える影響 (正方形陸屋根模型, 屋上設置壁高さ $0.0 \mathrm{~m}$ ) 


\section{2. 屋根勾配の影響}

片流れ屋根では図 $1(\mathrm{c})$ に示すように風上側隅角部において屋上設 置壁高さを定義した。屋上設置壁高さが $2.5 \mathrm{~m}$ の正方形片流れ屋根と 正方形陸屋根の, 屋根面の風上側に位置する $1 / 4$ の範囲における全風 向最小ピーク風圧係数の比較を図13に示す。図13に示す通り, 勾配 が5\%程度以下である片流れ屋根の風上側の領域における全風向最 小ピーク風圧係数は, 屋上設置壁高さの等しい陸屋根のものと同程 度であった。

\section{3. 気流の影響}

Flow1（粗度区分II）に比べて気流の乱れ強さの大きいFlow2（粗 度区分IV）を流入風に用いた際の軒高さが $10 \mathrm{~m}$ ，屋上設置壁無しの 正方形平面を持つ陸屋根の全風向最小ピーク風圧係数分布を図14に 示す。図8(a1)に示寸Flow1における計測結果と比較すると, 等值線 の現れ方は概ね等しかった。軒高さが $10 \mathrm{~m}$ である正方形平面を持つ 陸屋根にFlow 1, Flow2の風が当たる際の全風向最小ピーク風圧係数 の比較を図15に示す。Flow2の全風向最小ピーク風圧係数はFlow $1 の$ 全風向最小ピーク風圧係数と概ね比例関係にある。Flow1 とFlow2で は, べき指数, 乱れ強さが異なるため, これらが図15の軒高さによ る勾配の差の原因と推察される。

\section{5. 開口を有する屋上設置壁による屋根面のピーク風圧カの制御}

写真 2 に示寸ような, 開口を有する屋上設置壁を用いて屋根面に 作用するピーク風圧力の低減を試みた。屋上設置壁には図 16 に示す 4 種の配置で開口を設け，その開口率を屋上設置壁の見付面積に対 寸る開口部の総面積の比として定義し,開口の代表值とした。なお， ここに示寸結果は図 16 に示す 4 種類の開口による実験結果から導 かれたものである。

高さ $2.5 \mathrm{~m}$ の開口を有する屋上設置壁を付加した軒高さ $10 \mathrm{~m}$ の正 方形陸屋根における全風向最小ピーク風圧係数の分布を図 17 に示 す。図 8(a2)に示す開口の無い屋上設置壁における計測結果と比較す ると全風向最小ピーク風圧係数の最小值は同程度であるが, その分 布は大きく変化し, 開口があるとき屋上設置壁の無い陸屋根と同様 に等值線が壁面と平行であった。

荷重指針 2)を参考に屋根面を分割し, その各領域における全風向 最小ピーク風圧係数の平均值と屋上設置壁の開口率の関係を図 18 に示す。屋上設置壁の高さによらず開口率が $25 \%$ 程度となるとき, 全風向最小ピーク風圧係数の絶対值は最も小さくなった。

これらの結果は開口を設けることで壁を風が若干通過し，結果と して屋上設置壁がある場合とない場合の中間的な風圧分布が生じて いるためと推察される。そのうち, 開口率が $25 \%$ 程度となるときが 全風向最小ピーク風圧係数の絶対值を最も小さくするような風が通 過する開口率であったと思われる。

開口を有する屋上設置壁が全風向最小ピーク風圧係数に与える影 響を, 屋上設置壁の無い陸屋根と, 開口の無い屋上設置壁のある陸 屋根とそれぞれ比較し図 19 に示寸。図 19(a)は陸屋根との比較であ る。(a1)には全風向最小ピーク風圧係数の差を示す。陸屋根に対し 開口を有する屋上設置壁を付加すると, 屋根の外周部において全風 向最小ピーク風圧係数の絶対值は低減され，特にその絶対值が大き い隅角部付近において低減量が 5 割を超えた。一方で, 開口を有す る屋上設置壁を付加することで, 屋根面の中央部における全風向最

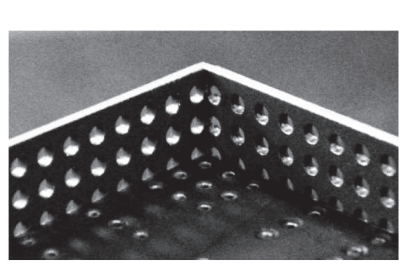

写真 2 開口を有する屋上設置壁

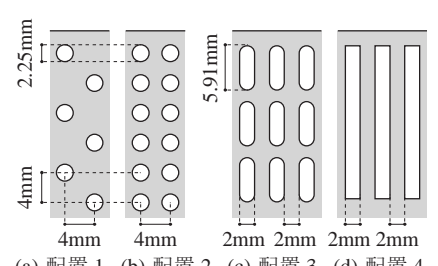

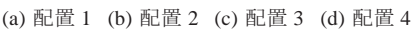
図 16 開口の配置

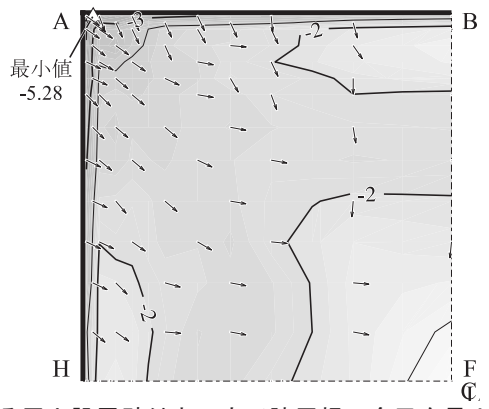

図 17 開口のある屋上設置壁付き正方形陸屋根の全風向最小ピーク風圧係数 （軒高さ $10 \mathrm{~m}$, 屋上設置壁高さ $2.5 \mathrm{~m}$, 開口率 23\%)

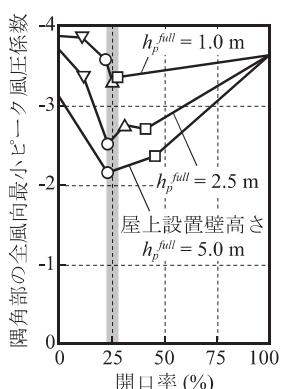

(a) 隅角部

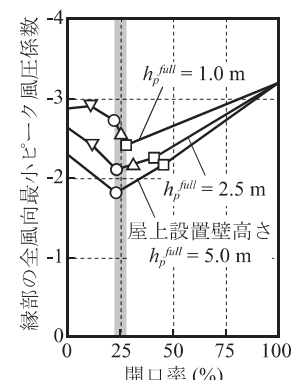

(b) 縁部

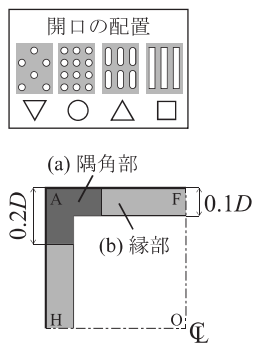

${ }^{\mathrm{O}} \mathrm{E}$

図 18 全風向最小ピーク風圧係数の領域平均の開口率による変化 (軒高さ $20 \mathrm{~m}$ )

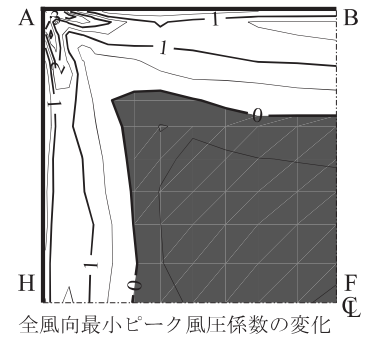

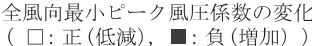

(a1) 開口を有する屋上設置壁による 全風向最小ピーク風圧係数の差
(開口ありの屋上設置壁あり) - (陸屋根)

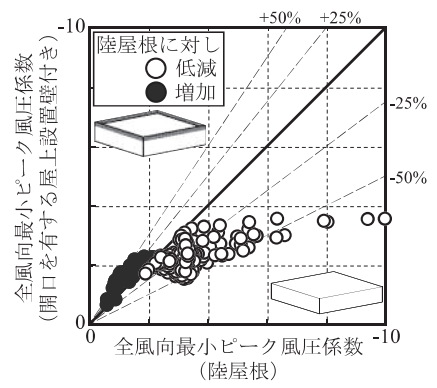

(a2) 各湘定点における 全風向最小ピーク風圧係数の比較

(a) 開口を有する屋上設置壁を陸屋根に付加した際の 全風向最小ピーク風圧係数の変化

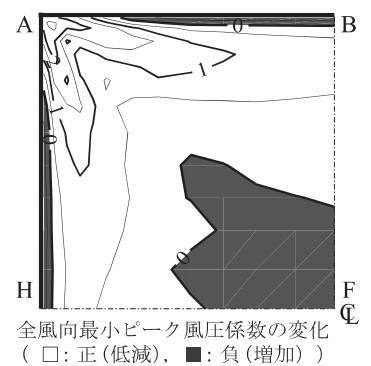

1) 屋上設置壁に開口を設けた際の 全風向最小ピーク風圧係数の差 (開口ありの屋上設置壁あり)

(開口なしの屋上設置壁あり)

(b)屋上設置壁に開口を設けた際の全風向最小ピーク風圧係数の変化

図 19 開口を有する屋上設置壁が全風向最小ピーク風圧係数へ与える影響 (軒高さ $20 \mathrm{~m}$ ，屋上設置壁高さ $2.5 \mathrm{~m}$ ，開口率 $23 \%$ ) 
小ピーク風圧係数は, 陸屋根に比べて増加したが, その増加量は非 常に小さかった。図 19(b)に示寸通り, 屋上設置壁に開口を設けると 屋根の外周付近において全風向最小ピーク風圧係数の絶対值は低減 され, 特にその絶対值が大きい隅角部付近ではその低減量が 3 割程 度となった。一方屋根の縁部において, 開口の無い場合に比べて全 風向最小ピーク風圧係数の絶対值が増加する測定点が多く確認でき る。これより，隅角部付近の夕に開口を設けることで，縁部におけ る全風向最小ピーク風圧係数の絶対值の増加を抑え, 全風向最小ピ ーク風圧係数の絶対值の低減効果をより高めることができる可能性 が示唆されたが，これは開口の範囲を含めて今後の課題である。

\section{6. 結}

本研究では屋上設置壁のある大規模建築物を対象に，屋根面上の 風圧力の性状を明らかにすることを目的とし，剛模型を用いた風洞 実験及び三次元流体解析から風の流れ場の構造や風圧力の性状につ いて分析した。また, 建物形状, 気流の違いなどの様々なパラメー タによる影響を明らかにした。さらに，屋上設置壁に開口を設ける ことで, 屋根面に作用するピーク風圧力の低減を試み, その効果と 開口の量に関して分析を行った。以下に得られた知見を示す。

1) 陸屋根に屋上設置壁を付加寸ることで, 屋根面中央部における 最小ピーク風圧力の絶対值は増加する領域も存在するが，全風向 中の最小ピーク風圧力の屋根面上の最小值の絶対值や, 風上側隅 角部及び縁部に作用する最小ピーク風圧力の絶対值は低減する。

2) 軒高さが $20 \mathrm{~m}$ 程度以下の低層建築物において全風向中の最小 ピーク風圧係数を決定する風向として, 屋上設置壁が無いときは 風向 $\theta=0^{\circ}, 90^{\circ}$ が支配的であるが, 屋上設置壁が高くなるに伴い風 向 $\theta=45^{\circ}$ が支配的になる。しかし, 軒高さが $40 \mathrm{~m}$ 程度以上の中層 建築物では屋上設置壁の高さによらず，全風向最小ピーク風圧係 数を決定する風向として $\theta=45^{\circ}$ が支配的である。

3) 正方形平面と辺長比 $1: 2$ の長方形平面を持つ陸屋根では屋上設 置壁の有無にかかわらず，屋根面に作用する全風向中の最小ピー ク風圧力は同程度である。

4) $5 \%$ 程度以下の勾配を有する屋根に対し, 屋上設置壁を付加した 場合その勾配の影響は非常に小さく, 風上側における高さの等し い屋上設置が付加された陸屋根と, 屋根面の最小ピーク風圧係数 は大きく変わらない。

5) 開口を有する屋上設置壁を陸屋根に付加することで，屋根面の 外周部，特に隅角部付近における全風向中の最小ピーク風圧係数 は，陸屋根や開口の無い屋上設置壁を付加した時に比べて3割程 度低減される。また, その全風向最小ピーク風圧係数の絶対値は, 風洞実験に用いた開口の形状の範囲において, 開口の量がパラペ ットの見付け面積に対して25\%程度のとき, 陸屋根に比べて最も 小さくなった。
参考文献

1) 染川大輔, 川口彰久 : パラペットの厚みが陸屋根のピーク風圧係数に与 える影響, 日本建築学会大会学術講演梗概集 (構造 I), pp.147-148, 2006.9

2) 大竹和夫 : 大規模建物の屋根外装材用ピーク外圧・風圧係数に関する研 究, 日本建築学会学術講演梗概集（構造 I), pp.217-218, 2008.9

3) European Committee for Standardization : EUROCODE 1:Basis of design and actions on structures, Part2.4 A ctions on structures-Wind actions, 2005

4) 建築物の構造関係技術基準解説書編集委員会 : 2015 年版 建築物の構造 関係技術基準解説書，全国官報販売協同組合，2015.6

5) 日本建築学会 : 建築物荷重指針・同解説<2015>, 日本建築学会, 2015.3

6) 谷池義人，谷口徹郎，両角達郎：種々の陸屋根面上に形成される円錐渦 のスイッチング現象解析, 第 15 回風工学シンポジウム論文集, pp.305-310, 1998.12

7) Gregory A.K opp, Christian M ans, David Surry: Wind effects of parapets on low buildings : Part4. Mitigation of corner loads with alternative geometries, J ournal of Wind Engineering, V ol.93, pp.873-888, 2005.10

8) S.Pindado, J.M eseguer: Wind tunnel study on the influence of different parapets on the roof pressure distribution of low-rise buildings, Journal of Wind Engineering and Industrial A erodynamics, Vol.91, pp.1133-1139, 2003.6

9) 谷口徹郎, 谷池義人, 西村宏昭: 負担面積と時間遅れの考慮したドーム 屋根面に関するPOD 解析, 第 14 回風工学シンポジウム論文集, pp.323-328, 1996.12

10) 中山昌尚，佐々木康人，田中 清，平澤光春，山本浩二：新しく導入さ れた多点同時測定システムの概要と正方形断面建物模型への適用，フジ 夕技術研究所報, 第 29 号, pp.61-66, 1993

11) 財団法人日本建築センター：実務者のための建築物風洞実験ガイドブッ ク 2008 年版, 全国官報販売協同組合, 2008.10

12) T.Ogawa, T.Suzuki, Y.Fukuoka : Large eddy simulation of wind flow around dome structures by the finite element method, J ournal of W ind Engineering and Industrial Aerodynamics, 46-47, pp.461-470, 1993.9

13）望月 勇，増田圭司，中山昌尚，小河利行：強風中の円筒屋根面の動的 挙動に関する研究, 第 15 回風工学シンポジウム論文集, pp.191-196, 1998.12

14) 小河利行, 綿貫雄太, 熊谷知彦, 安竹涼平, 増田圭司, 佐々木康人：直 線推動型 HP 屋根面に作用寸る風圧力の性状 サグスパン比が風圧力に与 える影響，構造工学論文集，Vol.59B，pp.497-503，2013.3

15) 片岡浩人, 水野 稔: 流入変動風を用いた三次元角柱周りの気流解析, 日本建築学会計画系論文集，第 523 号，pp.71-77， 1999.9

16) 古市 圭, 植松 康, 中村修治, 世良昌也：機械固定式防水システムの 動風圧評価に関する研究, 第 19 回風工学シンポジウム論文集, pp.471-476, 2006.12

17) 安竹涼平, 綿貫雄太, 小河利行, 熊谷知彦, 増田圭司, 佐々木康人 : 直 線推動型 HP 屋根面に作用する風圧力の性状，その 1 その 2，日本建築 学会大会学術講演梗概集（構造 I），pp.933-936，2012.9

18) 徳井公彰, 安竹涼平, 小河利行, 熊谷知彦, 増田圭司, 佐々木康人：強 風中の直線推動型 HP 屋根面の風応答特性，その 1 その 2, 日本建築学 会大会学術講演梗概集（構造 I），pp.1057-1060, 2013.8

19）服部彰仁，徳井公彰，小河利行，増田圭司，佐々木康人：サグスパン比 の小さな直線推動型 HP 屋根に作用する風圧力の性状, 日本建築学会大 会学術講演梗概集（構造 I），pp.745-746，2014.9

20）服部彰仁，徳井公彰，箕輪健一，小河利行，増田圭司，佐々木康人：屋 上設置壁のある大規模建築物屋根面に作用する風圧力の性状，その 1 その 2, 日本建築学会大会学術講演梗概集（構造 I），pp.801-804，2015.9 


\title{
CHARACTERISTICS OF WIND PRESSURE ON ROOFS OF \\ LARGE-SCALE BUILDINGS WITH WALLS ON THE ROOFTOP
}

\author{
Akihito HATTORI*1, Masaaki TOKUI*1, Ken'ichi MINOWA*2, \\ Toshiyuki OGAWA ${ }^{* 3}$, Keiji MASUDA ${ }^{* 4}$ and Yasuhito SASAKI*5 \\ ${ }^{* 1}$ Former Grad. Stud., Dept. of Arch. and Build. Eng., Tokyo Institute of Technology \\ ${ }^{* 2}$ Assist. Prof., Dept. of Architecture, Nippon Institute of Technology, Dr.Eng. \\ ${ }^{* 3}$ Prof. Emeritus, Tokyo Institute of Technology, Dr.Eng. \\ *4 Technology Development Division, FUJITA Corporation, Dr.Eng. \\ ${ }^{* 5}$ Technology Development Division, FUJITA Corporation, M.Eng.
}

\section{Introduction}

Recently, many large-scale factories and distribution warehouses have been constructed. In the case of these large-scale buildings, walls are often attached on the outer periphery of roofs in order to screen the drainage gradient and accommodate machinery. Previous studies have been conducted on the effect of parapets on the wind pressure. But there are a variety of factors and whose influence has not previously been well elucidated. A number of studies have investigated mitigating peak wind pressure through the use of porous parapet.

\section{Models and Outline of Wind Tunnel Test and Numerical analysis}

Wind tunnel tests and numerical analyses are conducted by using $1 / 222$ scale rigid models. Wind tunnel tests were intended to analyze the influence of several parameters and effect of parapets. Numerical analysis was used to make the flow around the building visible.

\section{The Worst Peak Suctions effect on the Roof}

The definition of the worst peak suction is the ensemble average of the worst pressure from each one of 8 data records of 10 minutes duration, where wind pressure is applied as a Simple M oving Average (averaging time is 0.12 seconds based on $1 \mathrm{~m}^{2}$ roofing).

\section{Streamlines around the Models and Eigenmode of Wind Pressure}

Streamlines around the models were made visible by using numerical analysis and eigenmodes of wind pressure are derived by using Proper Orthogonal Decomposition. Then, the characteristics of the flow and 1st eigenmode of buildings with parapets were discussed.

\section{The effect of each factor on the characteristic of wind pressure}

The effects of several parameters on the worst peak suctions affect on roofs were analyzed based on wind tunnel tests. The worst peak suctions are only slightly influenced by planar shape and roof geometry, so that those factors are negligible. But the proportional relationship between the magnitude of the worst peak suctions and the turbulence intensity of the approach flow was confirmed.

\section{Reduction of Worst Peak Suction by Using Porous Parapets}

Porous parapets can mitigate worst peak suction on outer periphery of roof. A nalyzing the worst peak suctions on corner and edge regions, it was determined that maximum reduction occurred when the openings comprised $25 \%$ of parapet's area.

\section{Conclusions}

1) By attaching parapets to the to the flat roofs, the magnitude of the worst peak suction affecting on the corner or edge region is decreased. But, in the central region, the magnitude is increased.

2) In the case of low-rise buildings (lower than about $20 \mathrm{~m}$ ) without parapets, the worst peak suction is induced in wind direction $\theta=0^{\circ}$ or $90^{\circ}$. But as parapets become higher, the worst peak suctions are induced in wind direction $\theta=45^{\circ}$. In the case of middle-rise buildings, the worst peak suction is induced in wind direction $\theta=45^{\circ}$ regardless of height of parapets

3) The worst peak suctions affect the roofs of square buildings and rectangular buildings with an aspect ratio is 1:2 to the same degree regardless of the height of parapets.

4) The worst peak suctions affect sloped roofs (5\% gradient) and flat roofs to the same degree if the heights of parapets are same. (The height of parapets attached to the sloped roof is defined as the maximum height of parapets.)

5) The magnitude of worst peak suction effects on the corner and edge region of roof is reduced more than $30 \%$ by using porous parapets. In this test, the magnitude of worst peak suction is lowest when the quantity of opening in parapet is $25 \%$ of parapet's area. 